\title{
Influence of Rain Water Harvesting Techniques on Yield, Root Development and Profitability of Pearl millet (Pennisetum glaucum L.) Under Rainfed Condition
}

\author{
Amar Kant Verma ${ }^{1 *}$, U.D. Awasthi ${ }^{1}$, Rahul Ranjan ${ }^{2}$ and Naval Kishor ${ }^{1}$ \\ ${ }^{1}$ Department of Soil Conservation and Water Management, ${ }^{2}$ Department of Soil Science and \\ Agricultural Chemistry, C S Azad University of Agriculture and Technology, \\ Kanpur -208002 (U.P.), India \\ *Corresponding author
}

A B S T R A C T

\begin{tabular}{l} 
Ke y w or d s \\
$\begin{array}{l}\text { Rain water harvesting, } \\
\text { Rainfed, Root } \\
\text { development, } \\
\text { Economic efficiency. }\end{array}$ \\
Article Info \\
$\begin{array}{l}\text { Accepted: } \\
15 \text { October } 2017 \\
\text { Available Online: } \\
10 \text { December } 2017\end{array}$ \\
\hline
\end{tabular}

Keywords

Rain water harvesting, Rainfed, Root

development,

10 December 2017

\begin{abstract}
A field experiment was conducted at Kanpur, Uttar Pradesh during two Kharif seasons of 2012 and 2013 to assess the relative productivity and profitability of pearlmillet (Pennisetum glaucum L.) as influenced by different low cost water harvesting techniques. The soil of the experimental field was sandy loam in texture with average fertility. Water harvesting techniques tested in the experiment were compartmental bunding, deep ploughing, raised and sunken bed, inter row water harvesting, inter-paired row water harvesting, scooping and flat sowing as control. The result revealed that different rain water harvesting techniques showed significant response over control in respect to yield, root development and monetary return. Among different water harvesting techniques, inter-paired row water harvesting (IPRWH) produced highest seed yield of 20.50 and $21.90 \mathrm{q} \mathrm{ha}^{-1}$ fetching Rs. 17512 and $20557 \mathrm{ha}^{-1}$ which exhibited maximum B:C ratio of 1.04 and 1.22 during 2012 and 2013, respectively.
\end{abstract}

\section{Introduction}

Rainfed agriculture plays an important role in contributing world food security. In India, area under rainfed agriculture is about $85 \mathrm{~m}$ ha representing 60 per cent net cultivated area and supports 40 per cent population of the country. Water is one of the most essential resource in day to day life is becoming scarce due to various reasons. The need to conserve water and its resources assumes more importance than ever before in the present scenario. With the improvement of agricultural production technology and industrial growth, the demand of water has increased manifold. India is endowed with rich diversity of natural resources. However, the need for food and nutritional security is increasing due to expanding population. One of the emerging situations, however is water shortage, either as a result of over exploitation for limited localized purposes or because of adequate management strategies. Rainfed agriculture is facing problems of decelerating growth coupled with sustainability concerns. The deceleration in yields and production is mainly due to failure of rainfed farming. The most effective means of achieving sustainable crop production is through rain water conservation (Mishra et al., 2010). Rain is the 
cheapest available source of water for crop production in arid and semi-arid regions. It has been possible to grow crops successfully in areas receiving low average rainfall through water harvesting system developed over the years (Singh et al., 2010). Water stress occurs when roots cannot satisfy enough water to evaporative demand of water transpiring from leaves (Gupta et al., 2011). Rain water harvesting is a century old technique to capture runoff from rainwater. The main objective is to create feasibility and resilience of rainfed farming to droughts and other environmental shocks and to increase water availability for growing crops and other human needs.

Pearlmillet (Pennisetum glaucum L.) is one of the most important rainy season crop of south west Uttar Pradesh. Moisture deficiency and low soil fertility are the main factors limiting crop production. It is possible to harvest good yield of pearlmillet, by ensuring adequate moisture conservation to meet out crop requirement during moisture stress condition where rainfall distribution is cause of concern for farmers (Singh and Verma, 1996).

The role of water harvesting technique is well known, however such information is lacking in the sub-tropical agro-ecosystem of Uttar Pradesh. Henceforth, keeping these problems in view, an attempt has been made under present sandy which may be quite helpful in planning suitable conservation measures.

\section{Materials and Methods}

An experiment was conducted during two consecutive Kharif seasons of 2012 and 2013 at Soil Conservation and Water Management Farm of C S Azad University of Agriculture and Technology, Kanpur, Uttar Pradesh. The soil of experimental field was sandy loam in texture with organic carbon $0.32 \%$, total nitrogen $0.03 \%$, available $\mathrm{P}_{2} \mathrm{O}_{5} 17.8 \mathrm{~kg} \mathrm{ha}^{-1}$, available $\mathrm{K}_{2} \mathrm{O} 155 \mathrm{~kg} \mathrm{ha}^{-1}$, $\mathrm{pH} 7.8$, electrical conductivity $0.37 \mathrm{dS} \mathrm{m}^{-1}$, wilting point $6.2 \%$, field capacity $18.6 \%$, water holding capacity $29.6 \%$, bulk density $1.46 \mathrm{Mg} \mathrm{m}^{-1}$, particle density $2.56 \mathrm{Mg} \mathrm{m}^{-1}$ and porosity $42.96 \%$. The experiment was conducted in randomized block design with three replications having seven treatments viz. $\mathrm{T}_{1}-$ Flat sowing, $\mathrm{T}_{2}-$ Compartmental bunding, $\mathrm{T}_{3}-$ Deep ploughing, $\mathrm{T}_{4}-$ Raised and sunken bed, $\mathrm{T}_{5}-$ Inter Row Water Harvesting (IRWH), $\mathrm{T}_{6}-$ Inter-Paired Row Water Harvesting (IPRWH), and $\mathrm{T}_{7}-$ Scooping. The mean annual rainfall of the area is about $800 \mathrm{~mm}$ and more than $80 \%$ rainfall occurs during the monsoon season (July to September). The crop pearlmillet cv 'Tata hybrid super boss' was sown on August 08 and August 27 during 2012 and 2013, respectively. Recommended package of practices and fertilizer doses were applied in different treatments. Crop was harvested on November 2 and December 4 during first and second year of experimentation.

The cost of cultivation was calculated by taking in to account the prevailing prices of the input and application cost of the relevant treatments.

Economics of different treatments was worked out to assess the most viable and remunerative water harvesting technique under rainfed condition. Economic efficiency in terms of $\mathrm{Rs} \mathrm{ha}^{-1} \mathrm{day}^{-1}$ was worked out by dividing the total net monetary returns by total duration of the crop.

Root study was done at harvest by selecting three plants from each treatment randomly. The roots were subjected to wash with a jet of water spray so that the fine rootlets are not broken. Observations were made on depth of root penetration, number of root plants ${ }^{-1}$ and dry weight of root plants $^{-1}$. 
Table.1 Effect of rain water harvesting techniques on root development, yield and yield response under different treatments

\begin{tabular}{|c|c|c|c|c|c|c|c|c|c|c|}
\hline \multirow[t]{2}{*}{ Treatments } & \multicolumn{2}{|c|}{ Root depth (cm) } & \multicolumn{2}{|c|}{$\begin{array}{c}\text { Dry weight of root } \\
\text { plant }^{-1}\end{array}$} & \multicolumn{2}{|c|}{$\begin{array}{l}\text { Number of roots } \\
\text { plant }^{-1}\end{array}$} & \multicolumn{2}{|c|}{$\begin{array}{l}\text { Seed yield } \\
\qquad\left(\mathbf{q ~ h a} \mathbf{~ h a ~}^{-1}\right)\end{array}$} & \multicolumn{2}{|c|}{$\begin{array}{c}\text { Yield response } \\
(\%)\end{array}$} \\
\hline & 2012 & 2013 & 2012 & 2013 & 2012 & 2013 & 2012 & 2013 & 2012 & 2013 \\
\hline $\mathbf{T}_{\mathbf{1}}$ Flat sowing (Control) & 36.81 & 37.25 & 15.18 & 15.90 & 236 & 239 & 15.25 & 16.85 & 15.25 & 16.85 \\
\hline $\mathbf{T}_{2}$ Compartmental bunding & 37.50 & 37.86 & 16.67 & 17.00 & 240 & 245 & 17.80 & 19.58 & 16.72 & 16.20 \\
\hline $\mathbf{T}_{\mathbf{3}}$ Deep ploughing & 37.00 & 37.68 & 16.00 & 16.47 & 238 & 242 & 17.50 & 19.33 & 14.75 & 14.71 \\
\hline $\mathbf{T}_{4}$ Raised and sunken bed & 38.90 & 39.00 & 17.14 & 17.90 & 241 & 249 & 18.85 & 21.15 & 23.60 & 25.51 \\
\hline $\mathbf{T}_{5}$ IRWH & 39.00 & 39.92 & 17.69 & 18.10 & 248 & 259 & 19.59 & 21.45 & 28.45 & 27.29 \\
\hline $\mathbf{T}_{6}$ IPRWH & 39.85 & 40.00 & 17.85 & 18.83 & 252 & 262 & 20.50 & 21.90 & 34.42 & 29.97 \\
\hline $\mathbf{T}_{7}$ Scooping & 38.42 & 38.67 & 17.02 & 17.65 & 244 & 252 & 18.36 & 20.10 & 20.39 & 19.28 \\
\hline $\mathrm{SE}(\mathrm{d})$ & 0.83 & 0.62 & 0.57 & 0.49 & 2.82 & 1.56 & 1.01 & 0.89 & - & - \\
\hline $\mathrm{CD}(\mathrm{P}=0.05)$ & 1.83 & 1.37 & 1.27 & 1.09 & 6.23 & 3.44 & 2.21 & 1.95 & - & - \\
\hline
\end{tabular}

Table.2 Effect of rain water harvesting techniques on economics under different treatments

\begin{tabular}{|c|c|c|c|c|c|c|c|c|c|c|}
\hline \multirow[t]{2}{*}{ Treatments } & \multicolumn{2}{|c|}{$\begin{array}{c}\text { (Cost of } \\
\left.\text { cultivation } \text { ha }^{-1}\right)\end{array}$} & \multicolumn{2}{|c|}{$\begin{array}{c}\text { Gross return (Rs. } \\
\left.\text { ha }^{-1}\right)\end{array}$} & \multicolumn{2}{|c|}{$\begin{array}{c}\text { Net return } \\
\left(\text { Rs. } \text { ha }^{-1}\right)\end{array}$} & \multicolumn{2}{|c|}{$\mathrm{B}: \mathrm{C}$ ratio } & \multicolumn{2}{|c|}{$\begin{array}{l}\text { Economic efficiency } \\
\qquad\left(\mathrm{Rs} \mathrm{ha}^{-1} \mathrm{day}^{-1}\right)\end{array}$} \\
\hline & 2012 & 2013 & 2012 & 2013 & 2012 & 2013 & 2012 & 2013 & 2012 & 2013 \\
\hline $\mathbf{T}_{\mathbf{1}}$ Flat sowing (Control) & 16078 & 16078 & 28902 & 30225 & 12824 & 14147 & 0.81 & 0.87 & 128.24 & 141.47 \\
\hline $\mathbf{T}_{2}$ Compartmental bunding & 17096 & 17096 & 32262 & 34075 & 15166 & 16979 & 0.88 & 0.99 & 151.66 & 169.79 \\
\hline $\mathbf{T}_{\mathbf{3}}$ Deep ploughing & 16927 & 16927 & 31347 & 33741 & 14420 & 16814 & 0.85 & 0.99 & 144.20 & 168.14 \\
\hline $\mathbf{T}_{4}$ Raised and sunken bed & 16969 & 16969 & 32245 & 36319 & 15276 & 19350 & 0.90 & 1.14 & 152.76 & 193.50 \\
\hline $\mathbf{T}_{5}$ IRWH & 16841 & 16841 & 33112 & 36712 & 16271 & 19871 & 0.96 & 1.17 & 162.71 & 198.71 \\
\hline $\mathbf{T}_{6}$ IPRWH & 16841 & 16841 & 34353 & 37398 & 17512 & 20557 & 1.04 & 1.22 & 175.12 & 205.57 \\
\hline $\mathbf{T}_{7}$ Scooping & 16715 & 16715 & 31921 & 34737 & 15206 & 18022 & 0.90 & 1.07 & 152.06 & 180.22 \\
\hline
\end{tabular}




\section{Results and Discussion}

\section{Root growth}

Developments of roots in terms of root depth, dry weight of roots plant ${ }^{-1}$ and number of roots were maximized in the treatment of inter paired row water harvesting technique, the minimum values of these parameters recorded under flat sowing $\left(\mathrm{T}_{1}\right)$. These results are in accordance with those of Kumar et al., (2004).

\section{Yield and yield response}

The yield and yield response was found highest in the treatment of IPRWH followed by IRWH (Table 1). The lowest values were recorded under flat sowing Angadi et al., (2004).

\section{Economics}

Cost of pearlmillet cultivation due to application of different low cost water harvesting techniques ranged from Rs. 16078 to Rs. 17096. Compartmental bunding increased the cost of application (Table 2). The application of water harvesting techniques increased the cost of cultivation which were compensated by gross and net return indicating higher $\mathrm{B}: \mathrm{C}$ ratio The highest gross (Rs. 34353 and 37398) and net return (Rs. 17512 and 20557) as well as benefit cost ratio (1.04 and 1.22) were recorded from the treatment getting IPRWH. The lowest values of these economic parameters were recorded under flat sowing (Control). Thus, technique of IPRWH was beneficial not only from crop productivity but more so from profitability point of view. Moreover, it is clear from the result shown by economic efficiency which exhibited similar trend of efficacy. The highest value was recorded (175.12 and 205.57 Rs. ha ${ }^{-1}$ day $^{-1}$ ) during the two different years.
The result of the present study very clearly brought out that among rain water harvesting techniques, inter-paired row water harvesting (IPRWH) significantly produced maximum seed yield of Pearlmillet (20.50 and $21.90 \mathrm{q}$ $\mathrm{ha}^{-1}$ ) and subsequent earning of Rs. 17512 and $20557 \mathrm{ha}^{-1}$ exhibiting highest $\mathrm{B}: \mathrm{C}$ ratio, root development as well as economic efficiency during the two years, respectively. Thus, the crop can be grown successfully by adopting low cost rainwater harvesting techniques (IPRWH) under rainfed alluvial soil of Uttar Pradesh.

\section{References}

Angadi, V.V., Hugar, A.Y. and Basavaraj. B. (2004). Evaluation of promising Kharif sorghum genotypes for their yield potential and fertility response. Karnataka Journal of Agricultural Sciences. 17: 539-541.

Gupta, Meenakashi, Kaur, S., Tiku, A.K., Gupta V. and Gupta. A. (2011). Crop productivity in relation to physiological changes under moisture stress condition. Journal of Soil \& Water Conservation. 10 (1): 34-39.

Kumar. N. and Gautam, R.C. (2004). Effect of moisture conservation and nutrient management practices on growth and yield of Pearl millet (Pennisetum glaumcum) under rainfed conditions. Indian Journal of Agronomy. 43: 182185.

Mishra, Purnima, Rao, B.V. and Ravi Babu R. (2010). Assessing the scope for rainwater harvesting in vertisols for sustainable agriculture and livelihood security of tribal farmers - a case study. Journal of Soil \& Water Conservation. 9 (2): 98-108.

Singh, Pratap and Verma, R.S. (1996). Nitrogen uptake and quality of pearlmillet as influenced by moisture conservation practices and $\mathrm{N}$ 
fertilization. Indian Journal of Soil Conservation. 24 (1): 85-89.

Singh, R.K., Prasad, S.N., Ali, S., Kumar, A., Singh, K.D., Prasad, A., Singh, S.V. and Parandiyal, A. K. (2005). On-farm evaluation of conservation measures to the performance of rainfed crop in semi- arid region. Indian Journal of Soil Conservation. 33 (2): 141-143.

Sinha, B.L., Nema A.K., Saha, R.K. and Pali A.K. (2010). Efficient utilization of harvested water in farm pond for growing mustard crop. Journal of Soil \& Water Conservation. 9 (2): 114-119.

\section{How to cite this article:}

Amar Kant Verma, U.D. Awasthi, Rahul Ranjan and Naval Kishor. 2017. Influence of Rain Water Harvesting Techniques on Yield, Root Development and Profitability of Pearlmillet (Pennisetum glaucum L.) Under Rainfed Condition. Int.J.Curr.Microbiol.App.Sci. 6(12): 17051709. doi: https://doi.org/10.20546/ijcmas.2017.612.192 